\title{
Chronodisruption: effects on reproduction, transgenerational health of offspring and epigenome
}

\author{
Leyla Sati \\ Department of Histology and Embryology, Akdeniz University School of Medicine, Antalya, Turkey \\ Correspondence should be addressed to L Sati; Email: leylasati@yahoo.com
}

\begin{abstract}
The circadian system regulates the daily temporal organization in behavior and physiology, including neuroendocrine rhythms and reproduction. Modern life, however, increasingly impacts this complex biological system. Due to limitations of working with human subjects exposed to shift work schedules, most chronoregulation research has used rodent models. Recent publications in these model systems have emphasized the negative effects of circadian rhythm disruption on both female and male reproductive systems and fertility. Additionally, there is growing concern about the long-term effects of circadian rhythm disruptions during pregnancy on human offspring and their descendants as circadian regulation during pregnancy can also alter epigenetic programing in offspring. However, to truly know if such concerns apply to humans will require retrospective and prospective human studies. Therefore, this review will highlight the latest available evidence regarding potential effects of chronodisruption on both female and male reproductive systems. Additionally, it presents a comprehensive summary of transgenerational and epigenetic effects on adult offspring that result from maternal chronodisruption.

Reproduction (2020) 160 R79-R94
\end{abstract}

\section{Introduction}

Circadian rhythms align the biological processes of an organism to 24-h environmental cycles. The internal timing system, or circadian clock, coordinates the rhythmic regulation of physiological and behavioral processes in mammals and includes food intake, nutrient processing, sleep/awakening, body temperature, hormone secretion, tissue repair and many others. A discordance between the ambient environment and the circadian rhythm is defined as chronodisruption. However, modern lifestyle factors such as shift work, night eating syndrome and sleep disorders can disrupt the inner rhythm and impair synchronization between the internal clock and the metabolic rhythm. Therefore, there are several reports indicating a link between shift work and obesity, diabetes, heart disease, and other metabolic conditions such as energy metabolism, adverse pregnancy outcomes and psychosocial mental disorders such as depression and anxiety and even with some types of cancers including breast cancer (Sun et al. 2018, Cai et al. 2019, Nikpour et al. 2019, Rosa et al. 2019, Rivera et al. 2020). A recent study also reported an association between rotating night shift work and earlier menopause among women particularly under the age of 45 years (Stock et al. 2019). In humans, even $2 \mathrm{~h}$ of 'social jetlag' (disruptions to the typical sleep wake cycle) is associated with an adverse endocrine, behavioral and cardiovascular risk profile in apparently healthy participants, further illustrating the significance of the circadian regulation on the biological and behavioral rhythms (Rutters et al. 2014). One of the limitations in this area of research is that the most studied laboratory animal models and species are nocturnal as compared to diurnal circadian process in humans.

Pregnancy also seems to induce circadian changes in daily rhythms in both mice and women, altering both time of onset and amount of physical activity at different stages of the pregnancy (Martin-Fairey et al. 2019). Furthermore, maternal circadian rhythm changes in these processes may potentially affect epigenetic programming in offspring. In this concept, circadian regulatory pathways might play an important role in the formation of circadian epigenomes and rhythmic epigenetic changes. However, the discovery of links between circadian rhythm, genetic determinants and related potential phenotypes are needed. Therefore, this review mainly focuses on the role of chronodisruption on both female and male reproduction. Moreover, the potential effects of maternal circadian regulation during pregnancy and lactation periods on the transgenerational health of the offspring and its epigenome are discussed.

\section{Molecular machinery of the mammalian circadian clock}

In mammals, circadian rhythms are driven by a master pacemaker in the suprachiasmatic nucleus (SCN) of the hypothalamus (Welsh et al. 2010). The current evidence 
suggests that there is not much difference for either the activity cycle or the efferent projections of SCNs of nocturnal versus diurnal species (Novak et al. 2000) and this is also conserved in humans. Photosensitive retinal ganglion cells project axons to the SCN creating the retinohypothalamic tract that the $\mathrm{SCN}$ uses to coordinate circadian rhythms. An oscillation process initiates and distributes this information over the whole organism by means of hormonal and autonomic signals to instruct cells that are not directly exposed to light. Even though the SCN acts as a central pacemaker atop this hierarchy, a surprising number of mammalian peripheral tissues appear to contain the molecular machinery necessary for circadian oscillation and on occasion, might exhibit dampened circadian oscillations even in the absence of the SCN. Both SCN and peripheral oscillators require regular periodic input from environmental stimuli called zeitgebers (German, time-giver) or synchronizers. Zeitgebers synchronize the internal clock network with external time. The most potent zeitgeber of the mammalian circadian system is the $24 \mathrm{~h}$ light: $24 \mathrm{~h}$ darkness cycle. In other words, Zeitgeber Time (ZT) refers to time relative to the onset of light, defined as ZT0 (lights on)-ZT12 (lights off), while the dark phase is defined as ZT12-ZT24. On the other hand, circadian time $(\mathrm{CT})$ is a standard unit of time based on the endogenous free-running period of a rhythm. However, how the signals generated in the SCN reach oscillators in the brain or other parts of the organism have not been fully elucidated and the function of genes in the circadian machinery in peripheral tissues generally is unclear.

Circadian rhythms are driven by transcriptiontranslation feedback loops (TTFLs) involving a number of central (core) clock genes, that is, Aryl hydrocarbon receptor nuclear translocator-like protein 1 (ARNTL) or brain and muscle ARNT-like 1 protein (BMAL1), circadian locomotor output cycles kaput (Clock), cryptochrome 1 and 2 (Cry1, Cry2) and period 1, 2, 3 (Per1, Per2, Per3) (Fig. 1). Even though the molecular circadian clock acts like a widespread cellular mechanism, alterations for different rhythmic functions exist from bacteria to animals. For instance, orthologous Drosophila clock genes are variably characterized in disparate species such as birds, rodents and humans, and genome-wide sequencing is emerging as a powerful tool in comparative genetics of circadian machinery in these different species.

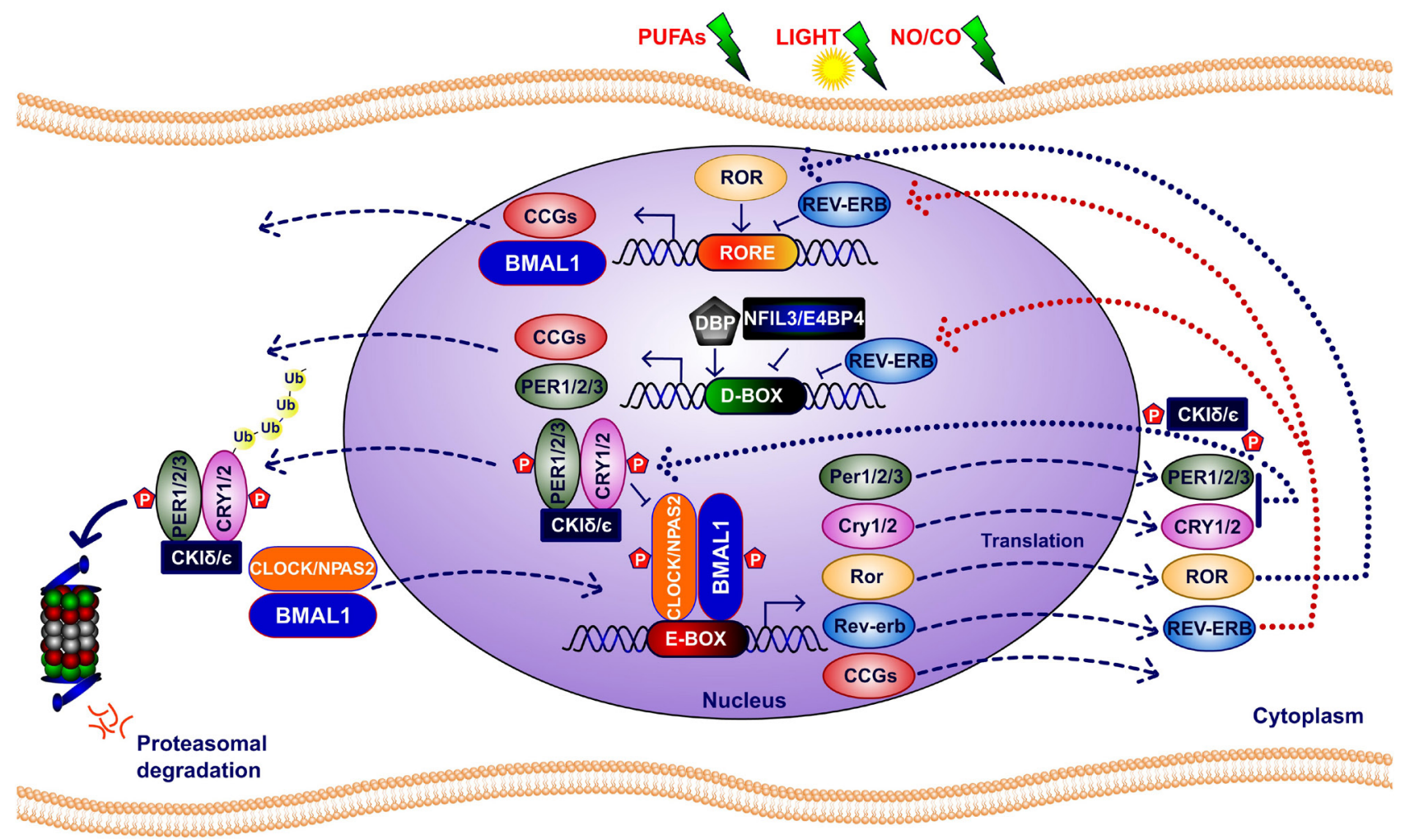

Figure 1 Molecular circadian core machinery in mammals. The transcriptional-translational feedback loops (TTFLs) are presented. The core clock genes as well as other clock-controlled genes (CCGs) are regulated through binding of different protein regulators to E-boxes, D-boxes or ROREs. Factors such as light, polyunsaturated fatty acids (PUFAs), carbon monoxide (CO) and nitric oxide (NO) can reset the circadian TTFL. Circadian locomotor output cycles kaput, CLOCK; Neuronal PAS domain protein 2, NPAS2; Muscle ARNT-Like 1 protein, BMAL1; Period 1, 2, 3, Per1, Per2, Per3; Cryptochrome 1 and 2, Cry1, Cry2; casein kinases, CKI $\delta$ and CKI $\varepsilon$; Retinoic acid-related orphan receptors, ROR $\alpha / \beta / \gamma ;$ Reverse erythroblastosis virus $\alpha / \beta$, Rev-erb $\alpha / \beta$ (Nr1d1/2); Retinoic acid-related orphan receptor response element, RREs or ROREs; Ubiquitin, Ub. 
CLOCK and NPAS2 (Neuronal PAS domain protein 2) are the transcriptional factors that play central and overlapping roles in the TTFLs and can both form heterodimers with BMAL1. To run the molecular clock, the CLOCK (or NPAS2) and BMAL1 heterodimer enters the nucleus and binds to the enhancer sequence E-box regulatory element in promoter region (CACGTG) of PER, CRY and other clock-controlled genes (CCGs). On the other hand, the accumulation of PER:CRY dimers in the nucleus inhibit the activity of the CLOCK:BMAL1 heterodimer and also control its transcriptional regulation. Casein kinases I epsilon $(\mathrm{CKI} \varepsilon)$ and delta $(\mathrm{CKI} / \delta)$ regulate the degradation of PER:CRY dimers. Casein kinase $\delta / \varepsilon$ phosphorylation of PER leads to destabilization of the PER1 complex resulting in its degradation.

Retinoic acid-related orphan receptors (ROR $\alpha / \beta / \gamma)$ and reverse erythroblastosis virus $\alpha / \beta$ (Rev-erb $\alpha / \beta, \mathrm{Nr} 1 \mathrm{~d} 1 / 2)$ recognize the retinoic acid-related orphan receptor response element (RREs or ROREs) in the BMAL1 promoter with a competition in secondary TTFL. They act in a way to stabilize the TTFLs that RORs activate while, on the contrary, REV-ERBs inhibit BMAL1 transcription. On the other hand, regulation of destruction (D)-boxes in the promoters of several clock genes preserves a different feedback mechanism for molecular circadian machinery (Jolley et al. 2014). D-box-dependent transactivation is repressed by Nuclear factor interleukin 3 regulated protein (NFIL3, E4BP4) although Albumin D-site-Binding Protein (DBP) rhythmically activates transcription of various genes through a D-box. Therefore, the components of circadian machinery are regulated by different ways of binding to E-boxes, D-boxes and ROREs (Fig. 1). The TTFL can be reset by PER gene transcription through light stimulation in the SCN. In addition to light stimulation, polyunsaturated fatty acids (PUFAs), carbon monoxide and nitric oxide can also downregulate circadian clock function (Lavialle et al. 2008, Minegishi et al. 2018). PUFAs activate peroxisome proliferator-activated receptors (PPARs) that regulate the transcription of some clock genes such as BMAL1, PER2 and REV-ERB $\alpha$ (Chen \& Yang 2014). These transcriptional feedback cycles take 24 $\mathrm{h}$ to complete and form the basis for the circadian rhythms. However, local physiological demands for cell-specific organization of circadian clocks such as extracellular matrix involvement with implications for acquisition of diseases have also been described (Streuli \& Meng 2019). Thus, circadian clock arrest in mammals may be due to defective TTFLs by different states of circadian system components. The emergence of the circadian machinery during mammalian development and its maintenance throughout life is not well-understood. In addition, it is known that nocturnal and diurnal species display opposite phases for several biological process including sleep/ wake cycles, hormonal and metabolic rhythms (Kumar Jha et al. 2015). Thus, it is of note that even though SCN projections seem similar between nocturnal and diurnal species, the response of the peripheral target areas might alter the interpretation of signals from the SCN (e.g. opposite effects of SCN-derived vasopressin within the area of the paraventricular nucleus in the hypothalamus on the release of corticosterone) (Kalsbeek et al. 2008). Additionally, the circadian regulation between nocturnal and diurnal species remains unclear. In seasonal breeders, such as short-day (e.g. sheep and goats) and long-day (e.g. horses) breeders, regulation of the molecular clock between these different species is yet unidentified in detail even though differences in the $24 \mathrm{~h}$ rhythmicity of plasma melatonin among these species was very recently demonstrated (Giannetto et al. 2020).

In a recent study, the genome-wide RNA transcriptome from peripheral blood mononuclear cells (PBMCs) between hospital nurses working day shift versus night shift, compared on a day off, indicated distinct gene expression patterns (Resuehr et al. 2019). This study analyzed the $24 \mathrm{~h}$ circadian transcriptome to allow proper alignment of circadian gene expression of PBMCs. However, only a relatively small sample size was studied and males were excluded. Also, this study did not restrict the use of agents such as oral contraceptives and caffeine which might influence the transcriptome. Another study reported alterations in the expression of genes such as Per3 and nuclear receptor subfamily 1 group $\mathrm{D}$ member $2(\mathrm{Nr} 1 \mathrm{~d} 2)$ in the molecular machinery for night shift workers depending on an individual's shift work type such as one night shift work versus consecutive night shift work versus daytime only, using hair follicle samples (Hattammaru et al. 2019). As in the previous study, only a small sample size for only one $24 \mathrm{~h}$ period was analyzed and, in this instance, female workers were excluded. Ideally, gender specific alterations should be considered over multiple $24 \mathrm{~h}$ circadian cycles. Molecular circadian dysregulation was also addressed in both central and peripheral clocks for police officers performing night shift work (Koshy et al. 2019). The study assessed urinary 6-sulfatoxymelatonin and salivary cortisol as central clock markers and clock gene expressions in oral mucosa cells and PBMCs as two different peripheral clocks in 11 police officers. It should be noted that all of these studies reported substantial differences between individuals, even within the same group. Since transcriptome alterations might depend on multiple factors, for example, the number of non-working days, the sleep/wake pattern during off-days, the work and off-work environments, and the health of the participants need to be considered when designing experiments and drawing conclusions. The tissue sampled and the conditions of sampling, such as ambient lighting, should also be considered.

\section{The role of circadian system in female reproductive biology}

The SCN has a well-defined role in the physiology of female reproduction. Initial evidence of circadian 
control of ovulation was found more than 50 years ago in rodent models. SCN peptides such as vasoactive intestinal polypeptide (VIP) and vasopressin were found to possibly act in concert to precisely coordinate the timing and generation of the luteinizing hormone (LH) surge and ovulation (Evans \& Anderson 2018). Ovarian theca cells are reported to play an important role in the timing of ovulation by modulating phasic sensitivity to LH (Mereness et al. 2016). After puberty the ovary shows a rhythmicity in circadian clock gene expression in large preantral, small antral and Graafian follicles and in corpora lutea (Sellix 2015). In particular, mice lacking Bmal1 reveal severe infertility with implications in ovarian luteinization (Alvarez et al. 2008). The LH surge is also reported to induce continuous expression of BMAL1 in the mouse ovary (Kobayashi et al. 2018). In addition to ovulation timing, the circadian clock in the ovary is important for steroidogenesis and follicular maturation (Chen et al. 2016). Furthermore, decreased expression of PER1 and CLOCK in older women (age 39-45 years) has been described (Brzezinski et al. 2018). Therefore, this may partially explain the decreased fertility and steroidogenesis in reproductive aging (Brzezinski et al. 2018).

Polycystic ovary syndrome (PCOS)-like changes in Sprague-Dawley rats are observed when the rats are kept under continuous light exposure for four consecutive weeks (Chu et al. 2019). Peripheral contributions may also mediate the circadian timing of ovulation, steroid production in follicular granulosa and theca cells, and oocyte development (Sellix 2015). Presently, the physiological importance of rhythmicity in clock gene expression in these cells is poorly defined. Unfertilized mouse oocytes express mRNAs of the six canonical clock genes (Per 1 and 2, Cry 1 and 2, Clock and Bmal1) (Johnson et al. 2002). Expression of these mRNAs decreases between the 2-cell and 16-cell stages but reappear at the blastocyst stage (Johnson et al. 2002). Clock mutant females show irregular estrous cycles (Miller et al. 2004). Lower number of oocytes, litter size, higher cell apoptosis and increased miscarriage risk are reported when female mice are injected with CLOCKshRNA (Li et al. 2015). Similarly, irregular estrous cycles and impaired ovulation are detected in mice without a functional Bmal1 gene (Boden et al. 2010) and repetitive reversal of light-dark cycles seems to trigger irregular estrous cycles in mice (Yoshinaka et al. 2017).

Recently, researchers questioned whether Rev-erb $\alpha$ is involved in the balance between pro-inflammation and anti-inflammation in human endometrial stroma cells (hESCs) and whether it plays a potential role in maintaining the menstrual cycle and embryo implantation (Zhao et al. 2019). The results suggested that pharmacological activation of Rev-erbo attenuated the lipopolysaccharide (LPS)-induced inflammatory response of hESCs by suppressing TLR4-regulated NF- $\mathrm{KB}$ activation providing a potential strategy for the treatment of inflammation-related endometrial dysfunction and infertility or recurrent implantation failure.

Studies of reproductive function in shift workers are of great interest. These workers experience sleep disturbances and exposure to light at night which could increase their risk for altered circadian physiology. Thus, a number of studies report negative effects of chronodisruption in shift workers. Particularly, the importance of circadian rhythm release of LH for ovulation in female shift workers have been investigated by several groups. A systematic review reported that 13 of 20 studies investigated pregnancy, 3 addressed fertility and 4 the menstrual cycle (Chau et al. 2014). Only one prospective investigation of the association of night work and age at natural menopause exists (Stock et al. 2019). Irregular and longer menstrual period and mood disturbances are found to be associated with shift work (Labyak et al. 2002, Lawson et al. 2011, Boden et al. 2013, Wang et al. 2016). Deterioration of the menstrual cycle increases as the duration of chronodisruption increases (Lawson et al. 2011). Similarly, social jet lag, equivalent to traveling across multiple time zones, and severe menstrual symptoms for female university students has been reported (Komada et al. 2019). Interestingly, some investigators even suggested that the changes in menstrual regularity may be a marker of shift work intolerance (Labyak et al. 2002). Irrespective of whether this is true, most of the studies point to problems in reproductive physiology with night shift exposure. However, overall, there is no clear evidence to restrict women from working night shifts (Stock \& Schernhammer 2019). The animal and human studies relevant to circadian regulation important for female reproductive biology are summarized in Table 1.

\section{The role of circadian system in male reproductive biology}

Expression of Clock, Bmal1, Per1, Per2, Cry1 and Npas2 genes were constant at all times when total RNA was extracted from mouse testes at various times of day (Alvarez et al. 2003). However, whether there is weak or no rhythmicity in testes is controversial (Li et al. 2020b). Thus, circadian clock genes have been suggested to play alternative roles aside from creating rhythmicity. CLOCK expression is restricted to round spermatids, specifically within the developing acrosome (Alvarez et al. 2003). Alterations in PER1 protein expression in spermatogonia and the condensing spermatids have been reported during sperm maturation (Alvarez et al. 2003). Furthermore, some circadian clock genes are associated only with certain stages of sperm development so that, for example, Per1 mRNA expression is limited to stages $7-10$ of the cycle in mice seminiferous epithelium (Alvarez et al. 2003, Morse et al. 2003). Therefore, current data supports the idea that genes in the circadian machinery may have 
Table 1 Summary of main animal and human studies mentioned in this review for circadian regulation of female reproductive biology.

\begin{tabular}{|c|c|c|}
\hline Reference & Species or subjects & Major implications \\
\hline \multicolumn{3}{|l|}{ Animal studies } \\
\hline Boden et al. (2010) & Homozygous Bmal1 null mice & Ovulation timing and problems (LH-surge) \\
\hline Mereness et al. (2016) & $\begin{array}{l}\text { Bmal1 knockout in ovarian granulosa cells or } \\
\text { theca cells }\end{array}$ & Ovulation timing and problems (LH-surge) \\
\hline Kobayashi et al. (2018) & $\begin{array}{l}\text { Mice administered with human chorionic } \\
\text { gonadotropin }\end{array}$ & Ovulation timing and problems (LH-surge) \\
\hline $\begin{array}{l}\text { Evans \& Anderson } 2018 \\
\text { (review) }\end{array}$ & & Ovulation timing and problems (LH-surge) \\
\hline Miller et al. (2004) & Clock mutant mice & Irregular estrous cycles \\
\hline Boden et al. (2010) & Homozygous Bmal1 null mice & \\
\hline Yoshinaka et al. (2017) & $\begin{array}{l}\text { C57BL6 mice with repetitive reversal of } \\
\text { light-dark cycles }\end{array}$ & \\
\hline Li et al. (2015) & Mice injected with CLOCK-shRNA & $\begin{array}{l}\text { Lower number of oocytes, litter size and higher cell apoptosis, } \\
\text { increased miscarriage risk }\end{array}$ \\
\hline Alvarez et al. (2008) & Bmal1 knockout mice & Infertility on females (and also males) \\
\hline Chu et al. (2019) & $\begin{array}{l}\text { Sprague-Dawley rats kept under continuous } \\
\text { light exposure }\end{array}$ & Polycystic ovary syndrome (PCOS)-like changes \\
\hline \multicolumn{3}{|l|}{ Human studies } \\
\hline Chen et al. (2016) & $\begin{array}{l}\text { Human luteinized granulosa cells (after } \\
\text { testosterone treatment) }\end{array}$ & $\begin{array}{l}\text { Potential relationship between the circadian clock, } \\
\text { steroidogenesis and follicular maturation in the human ovary }\end{array}$ \\
\hline Brzezinski et al. (2018) & $\begin{array}{l}\text { Human luteinized granulosa cells from } \\
\text { young and older patients }\end{array}$ & $\begin{array}{l}\text { Decreased expression of some circadian genes in older } \\
\text { women, a potential implication for reproductive aging }\end{array}$ \\
\hline Zhao et al. (2019) & $\begin{array}{l}\text { Human endometrial stroma cells with } \\
\text { pharmacological activation of Rev-erb } \alpha\end{array}$ & $\begin{array}{l}\text { Rev-erb } \alpha \text { association with inflammation-related endometrial } \\
\text { dysfunction, infertility or recurrent implantation failure }\end{array}$ \\
\hline Labyak et al. (2002) & 68 nurses $<40$ years old & Menstrual cycle irregularity \\
\hline Lawson et al. (2011) & 71,077 nurses aged $28-45$ years & Menstrual cycle irregularity \\
\hline Wang et al. (2016) & Shift $(n=334)$ and non-shift workers $(n=139)$ & Menstrual cycle irregularity \\
\hline Komada et al. (2019) & $\begin{array}{l}150 \text { university students/social jet } \\
\text { lag association }\end{array}$ & Menstrual cycle irregularity \\
\hline Stock et al. (2019) & Rotating night shift workers/nurses & Moderate risk for earlier menopause \\
\hline
\end{tabular}

non-circadian roles in spermatogenesis. A physiological role for testis clock-associated genes is also supported by the finding that exposure to short day length induces more rhythmic Bmal1 mRNA expression with gonadal regression in hamsters (Tong et al. 2004). An interesting hypothesis suggested that the timing of expression of all clock and CCGs may depend on the relative presence of E-box, RORE, and DBP-binding elements (DBPE).

Low serum testosterone levels with low StAR protein expression in Bmal1 knockout (KO), Per2 KO and Per1/ Per2 double KO mice has also been shown (Alvarez et al. 2008). The Clock gene is suggested to regulate acrosin activity in sperm, further implicating circadian genes in male reproduction (Cheng et al. 2016). The effects of androgens on PER2::luciferase expression in a direct and tissue-dependent process has been reported in female mice (Mereness et al. 2015). Also, relatively short-term (11 days) exposure to inhibitory photoperiods has been shown to induce local and location-specific changes in androgen receptor expression. An inverse relationship between melatonin synthesis and testosterone levels has also been reported in mouse Leydig cells and involves melatonin receptors regulating hCG-induced testosterone synthesis (Gao et al. 2019). This information could be important in explaining how day length modifies gonadal steroid hormones and an interaction between testosterone and photoperiod can add to our understanding of environmental regulation of neuroendocrine function.

Daily changes in clock gene expression and protein abundance of PER1 and BMAL1, and various effector genes such as vacuolar-type H+-ATPase (V-ATPase) and carbonic anhydrase (CA-II), important for ion homeostasis in the male mammalian reproductive tract, exist in the epididymis (Bebas et al. 2009). Therefore, these genes may maintain an optimum environment in the epidydimal lumen for maturation and stability of sperm. Temporal changes in Per1 and Bmal1 gene expression in vas deferens, seminal vesicles and prostate have also been shown (Bebas et al. 2009). However, the significance of these changes is still unclear.

Sperm production is strictly regulated but the functional significance of the circadian rhythm in human testicular function is not fully understood. A study of 12,245 semen samples from 7068 males showed that semen quality (total sperm count, sperm motility or normal morphology) varied according to both circadian and circannual rhythms in humans (Xie et al. 2018). Increased length of daylight positively correlated with progressive sperm motility as well (Mao et al. 2017). Genetic epidemiological studies have also shown that circadian clock gene polymorphisms are linked to semen parameters and risk for infertility. A case-control 
study investigated polymorphisms in the CLOCK and ARNTL genes in 961 Slovenian and Serbian Caucasian men and showed that genetic variability in CLOCK might be associated with male infertility suggesting a non-circadian function of CLOCK (Hodzic et al. 2013). In a study of CLOCK knockdown in mice with small hairpin RNA, a significant reduction in offspring from these males was observed (Liang et al. 2013). In addition, Cry $1 \mathrm{KO}$ mice have perturbed spermatogenesis with increased number of degenerate and apoptotic germ cells in the testis and lower epididymal sperm counts ( $\mathrm{Li}$ et al. 2018). Bioinformatic analysis reveals that the differentially expressed genes are involved in important biological processes including cell-cell communication, metabolism, chromatin reorganization, spermatogenesis, and the immune response, indicating that Cry 1 is important for normal testicular function (Li et al. 2018).

Just like with female shift workers, male shift workers have also been studied. A study compared seminal parameters and urinary 5-HIIA levels (an indirect measure of serotonin) in night shift workers between recent fathers and infertile men, all of whom performed night shift work (Ortiz et al. 2010). The study revealed that high urinary 5-HIIA levels, and therefore high serotonin, may impair sperm quality and thus cause male infertility in night shift workers (Ortiz et al. 2010). However, caution is needed for the use of serotonin in infertility treatment or male contraception and further studies are definitely required. In addition, $\mathrm{Ni}$ and colleagues recently reported interesting data from 11,382 semen samples from two populations and in vivo animal experiments demonstrating that sperm DNA fragmentation index (DFI) may undergo diurnal variation ( $\mathrm{Ni}$ et al. 2019). These data are important since the existence of a circadian rhythm in DFI can explain the conflicting results observed in different studies related to sperm DFI since the 'timing' of the sample collection is not always considered. On the other hand, it may also underscore altered management for couples who need better semen quality for IVF treatments. Unfortunately, direct investigation of shift work on sperm quality is difficult due to difficulties to ensure environmental standardization for individuals in human studies. Thus, currently, shift work is not convincingly associated with either semen parameters or testosterone levels so far (Peterlin et al. 2019) and comprehensive epidemiological studies with large groups of men with appropriate controls for relevant confounders are needed. As with the circadian regulation of female reproductive biology, a summary of the animal and human studies for male reproductive biology are presented in Table 2.

\section{Circadian rhythm and pregnancy: does chronodisruption negatively affect pregnancy?}

Growing evidence suggests that early embryo development, uterine implantation, placentation and delivery may all be influenced by molecular machinery in the circadian system in rodents and other mammals. When mice are exposed to phase delays or advances in the light-dark cycle after copulation, reduced proportion of pregnancies carried to term is observed (Summa et al.

Table 2 Summary of main animal and human studies mentioned in this review for circadian regulation of male reproductive biology.

\begin{tabular}{|c|c|c|}
\hline Authors & Animals or subjects & Major implications \\
\hline \multicolumn{3}{|l|}{ Animal studies } \\
\hline Alvarez et al. (2003) & C57BL/6 mice & Non-circadian roles in spermatogenesis \\
\hline Morse et al. (2003) & $\begin{array}{l}\text { Clock }^{c / c} \text { mutant mice, } \\
\text { Per }^{-/ /} \text {mice, } C R E M^{-1 / \text { mice }}\end{array}$ & Non-circadian roles in spermatogenesis \\
\hline Liang et al. (2013) & CLOCK knockdown in testis/mice & \\
\hline Li et al. (2018) & Cry1 knockout mice & Cry 1 required for normal testicular function \\
\hline Alvarez et al. (2003) & $\mathrm{C} 57 \mathrm{BL} / 6$ mice & $\begin{array}{l}\text { Circadian regulation important for sperm maturation } \\
\text { and stability }\end{array}$ \\
\hline Bebas et al. (2009) & C57BL/6 mice & \\
\hline Alvarez et al. (2008) & Bmal1 knockout mice & $\begin{array}{l}\text { Bmal1 involvement in testosterone production and } \\
\text { fertility }\end{array}$ \\
\hline Mereness et al. (2015) & PER2::LUC transgenic mice & $\begin{array}{l}\text { Association with androgen and circadian gene } \\
\text { expression }\end{array}$ \\
\hline Liang et al. (2013) & CLOCK knockdown in testis/mice & Reduced fertility \\
\hline Cheng et al. (2016) & CLOCK knockdown in testis/mice & Reduced fertility \\
\hline \multicolumn{3}{|l|}{ Human studies } \\
\hline Ortiz et al. (2010) & $\begin{array}{l}\text { Men attending infertility counseling rotating shift } \\
\text { workers }(n=40)\end{array}$ & Risk for infertility \\
\hline Hodzic et al. (2013) & $\begin{array}{l}\text { Patients with idiopathic infertility }(n=517) \text { and fertile } \\
\text { men }(n=444)\end{array}$ & $\begin{array}{l}\text { Genetic variability in CLOCK associated with male } \\
\text { infertility }\end{array}$ \\
\hline Mao et al. (2017) & $\begin{array}{l}\text { Cases for routine semen analysis }(n=8168) \\
\text { morphology }(n=5819) \text { and anti-sperm antibodies } \\
\text { analysis }(n=5544)\end{array}$ & $\begin{array}{l}\text { Positive correlation between increased length of } \\
\text { daylight and progressive sperm motility }\end{array}$ \\
\hline Xie et al. (2018) & 12,245 semen samples $(n=7068$ men $)$ & Circadian and circannual variations on semen quality \\
\hline $\mathrm{Ni}$ et al. (2019) & Human semen samples $(n=10,752)$ & Diurnal variations on sperm DNA fragmentation \\
\hline
\end{tabular}


2012). Clock mutation also disrupts the ability to complete pregnancy (Miller et al. 2004). Circadian clock genes such as Per1 and Per2 are expressed rhythmically in the rat uterus during non-pregnancy and pregnancy (Akiyama et al. 2010). The conditional deletion of Bmal1 in the mouse ovary results in complete failure of implantation (Liu et al. 2014). Systemic deletion significantly reduces oocyte fertilization, early embryo development as detected by blastocyst number, and implantation in $\mathrm{Bmal1}^{-1-}$ mice compared with that of Bmal1 $1^{+/+}$mice after superovulation and in vivo or in vitro fertilization (Xu et al. 2016). Bmal1/-/- mice have increased intracellular reactive oxygen species (ROS) levels in the ovary on proestrus day and in the oviduct on metestrus day when compared to $\mathrm{Bmal1}^{+/+}$mice suggesting that excess ROS levels in ovary and oviduct negatively impact early reproductive events. This study, however, is limited by a relatively small sample size and more research will be needed to confirm these observations. More work will also be needed to better understand other ways circadian rhythm gene expression influences fertility and early embryo development.

Long photoperiodic exposure (18 h light: $6 \mathrm{~h}$ darkness) significantly reduces the number of implantation sites in mice compared to controls (Zhang et al. 2017). Goldstein and colleagues exposed mice to repetitive phase advances of the photoperiod (advance of lights on and lights off by 6 h every 4 days) and used them as recipients for embryo transfer using embryos from normal light-dark cycle mice (Goldstein et al. 2018). Thus, this investigation studied the effects of maternal chronodisruption on early gestation and uterine receptivity. The results are interesting since the pup and placental weights were found to be similar between groups, and uterine receptivity and maintenance of early gestation was preserved despite recurrent phase advances in the photoperiod (Goldstein et al. 2018). This study suggests that the negative effects of chronodisruption are mediated by reproductive processes upstream of implantation. Therefore, factors contributing to embryo quality and/or early embryo development may be the reproductive mechanisms most sensitive to the negative effects of chronodisruption.

On the other hand, it is reported that chronic phase shift (CPS) throughout gestation in rodents alters circadian rhythms of maternal corticosterone, glucose, insulin, leptin, free fatty acids, triglycerides and cholesterol and disrupts the timing of food intake and the hepatic clock and metabolic gene expression (Varcoe et al. 2013). There is no data to show that the variations in the timing of insemination in humans play a critical role in embryo viability. Thus, it remains possible that the low fertility rate observed in humans compared with other species could be partly due to inappropriate timing of uterine clock gene expression critical for implantation and embryo viability. Gatford and colleagues demonstrated that shift work during pregnancy can influence maternal circadian rhythms and metabolism, with differential effects on pregnancy outcomes in singleton and twin pregnancies with an increased length of gestation in twin pregnancies (Gatford et al. 2019). On the other hand, shift/night working conditions have been reported to increase the risk of endometriosis (Marino et al. 2008), miscarriage (Grajewski et al. 2015, Begtrup et al. 2019) and early, but not late, preterm birth (Lawson et al. 2012) in women. An abnormal expression of CLOCK is also detected in human fetuses from spontaneous miscarriage (Li et al. 2015). Several epidemiological studies have also suggested a relationship between shift work or repeated travel across time zones and decreased fertility as well as negative pregnancy outcomes such as increased incidence of low birth weight, preterm birth or miscarriage (Reschke et al. 2018, Mills \& Kuohung 2019, Suzumori et al. 2020). Researchers have begun to explore options to alter circadian rhythms to control the timing of birth to prevent poor pregnancy outcomes such as preeclampsia and preterm birth (McCarthy et al. 2019). In fact, a recent study reported that the Clock gene is involved in the hypoxic process of preeclampsia ( $\mathrm{Li}$ et al. 2020a). In line with these studies, a hypothesis was presented that light at night due to shift work suppresses melatonin synthesis and potentially leads to metabolic disorders in the offspring (Nehme et al. 2019). However, it is difficult to conclude whether these adverse outcomes are caused by circadian dysregulation or some other lifestyle factors (for instance poor sleep quality) associated with shift work. In addition, later sleep timing and circadian phase position during pregnancy is found to be associated with greater risk of increased psychiatric and psychologic symptoms across several cognitive, behavioral, and regulatory domains (Obeysekare et al. 2020). In contrast, a recent paper reported no relationship between shift work and fecundability in a North American preconception cohort study (Willis et al. 2019). The overall implications of the circadian regulation on pregnancy outcomes are summarized in Table 3.

The role of melatonin in oocyte quality, ovarian and luteal function, fertilization, embryo implantation, pregnancy and parturition in women undergoing assisted reproductive treatment and in patients with PCOS undergoing intrauterine insemination and incidence of endometriosis and preeclampsia have also been reported (Chuffa et al. 2019, Scarinci et al. 2019). For instance, melatonin treatment resulted in beneficial effects in pregnant mice, especially those subjected to long photoperiodic exposure by enhanced embryo implantation, increased E2 levels during pregnancy and up-regulated p53 expression by activating melatonin receptors MT1/2 in the uterus (Zhang et al. 2017). What functional importance the circadian clock genes play in uterine preparation for early development and implantation will likely be important areas of future research. 
Table 3 Summary of main animal and human studies mentioned in this review for circadian system and chronodisruption in pregnancy.

\begin{tabular}{|c|c|c|}
\hline Authors & Animals or subjects & Major implications \\
\hline \multicolumn{3}{|l|}{ Animal studies } \\
\hline Miller et al. (2004) & Clock mutant mice & Disruption of maintenance of pregnancy \\
\hline Summa et al. (2012) & C57BL/6J (B6) mice & \\
\hline Liu et al. (2014) & Bmal1 knockout in ovarian steroidogenic cells & Failure of implantation \\
\hline Xu et al. (2016) & Bmal1 ${ }^{-1-}$ mice & $\begin{array}{l}\text { Reduced oocyte fertilization, early embryo development } \\
\text { and implantation; Increased intracellular ovarian ROS }\end{array}$ \\
\hline Zhang et al. (2017) & $\begin{array}{l}\text { Kun Ming (KM) mice; Long photoperiodic exposure } \\
\text { (18 h light:6 h darkness) }\end{array}$ & Reduced number of implantation sites \\
\hline Goldstein et al. (2018) & C57BL/6J X DBA/2J mice; Repeated light-dark shifts & $\begin{array}{l}\text { Preserved uterine receptivity and maintenance of early } \\
\text { gestation }\end{array}$ \\
\hline Gatford et al. (2019) & Simulated shift work in sheep & Differential effects on pregnancy outcomes \\
\hline \multicolumn{3}{|l|}{ Human studies } \\
\hline Grajewski et al. (2015) & Flight attendants $(n=673)$ and teachers $(n=91)$ & Miscarriage \\
\hline Begtrup et al. (2019) & $\begin{array}{l}\text { Women registered }(n=10,047) \text { and non-registered } \\
(n=12,697) \text { night shift during pregnancy week } \\
3-21\end{array}$ & \\
\hline Lawson et al. (2012) & US nurses ( $n=7482$ eligible for analysis) & Increased risk of early but not late preterm birth \\
\hline Li et al. (2015) & Fetuses from spontaneous miscarriage $(n=58)$ & $\begin{array}{l}\text { Abnormal CLOCK expression association with spontaneous } \\
\text { miscarriage }\end{array}$ \\
\hline Ohhashi et al. (2017) & Placental abruptions $(n=115)$ & $\begin{array}{l}\text { Association between circadian variations and pathogenesis } \\
\text { of placental abruption }\end{array}$ \\
\hline Suzumori et al. (2020) & Women with singleton pregnancies $(n=99,744)$ & $\begin{array}{l}\text { Chronodisruption associated with decreased fertility, } \\
\text { negative pregnancy outcomes such as increased incidence } \\
\text { of low birth weight, preterm birth or miscarriage }\end{array}$ \\
\hline \multicolumn{3}{|l|}{ Reschke et al. (2018) } \\
\hline \multicolumn{3}{|l|}{ Mills \& Kuohung (2019) } \\
\hline \multicolumn{3}{|l|}{ Bates \& Herzog (2020) } \\
\hline Marino et al. (2008) & $\begin{array}{l}\text { Women with endometriotic disease }(n=235) \text { and } \\
\text { controls }(n=545) / \text { Night shift work }\end{array}$ & Increased risk of endometriosis \\
\hline Li et al. (2020b) & $\begin{array}{l}\text { Patients with preeclampsia ( } n=20 \text { placenta) and } \\
\text { human cytotrophoblastic cell line HTR-8/SVne }\end{array}$ & $\begin{array}{l}\text { Clock gene involvement in the hypoxic process of } \\
\text { preeclampsia }\end{array}$ \\
\hline Willis et al. (2019) & Women aged $21-45$ years attempting pregnancy & No association between shift work and fecundability \\
\hline
\end{tabular}

\section{Effects of maternal circadian chronodisruption on fetal and postnatal development into adulthood}

Circadian rhythms emerge gradually in humans but develop rapidly in the postnatal period (Umemura \& Yagita 2020). Thus, it is important to examine the development of the fetal circadian system and how the maternal rhythm influences fetal oscillations. The fetal pineal gland does not secrete melatonin in human, sheep or rats and the circadian rhythm in the fetus is primarily controlled by the maternal system. Lipophilic melatonin passes freely through the placenta unchanged and provides light-to-dark information to the fetus although details of how that information is transferred is still not clear. Therefore, there is a growing concern about the long-term effects of maternal circadian rhythm disruptions on human offspring (and their descendants) through lifestyle and shift work during pregnancy (Hsu \& Tain 2020).

In a study in which pregnant rats were exposed to a CPS protocol that completely reversed the photoperiod every 3-4 days throughout gestation and the first week after birth, increased whole body insulin resistance in the adult offspring leading to a number of metabolic disruptions including obesity, hyperleptinemia, age and sex-related increases in glucose metabolism and metabolic syndrome were observed (Varcoe et al. 2011). Therefore, disruption in the developing circadian clock may play a causal role in the onset of metabolic syndrome. However, there is always a possibility that these alterations in the adult offspring might be a consequence of the reduced glucose tolerance and insulin sensitivity of the CPS exposed mothers. Moreover, this experimental design, does not identify if a specific period of gestation or postnatal development is more crucial for the development of metabolic syndrome. Maternal, but not paternal, circadian preference was found to be associated with infants' circadian rhythm development in early childhood (Morales-Munoz et al. 2019). Recent studies also suggest that chronodisruption during the neonatal period, when synchronization of the infant's circadian rhythms occur, might have long and short-term health consequences, potentially causing chronic stress-associated disorders (Astiz \& Oster 2018, McKenna \& Reiss 2018). However, demonstration of more detailed circadian effects on adverse neonatal outcomes in different subgroups will require more data.

In addition, gestational chronodisruption has been shown to alter both fetal and adult adrenal function and change the fetal adrenal transcriptome (Salazar et al. 
2018). These alterations are likely to have long-term adverse effects on the developing fetus and adult offspring (Varcoe et al. 2018). In contrast, a study reported that night shift work before and during pregnancy does not increase the risk of children developing atopic dermatitis, asthma or hay fever (Rada et al. 2020). Although, the study included detailed information of mothers and offspring with analysis of multiple potential confounding variables, it had limited power for the assessment of paternal information. Incidence of atopic disease was solely self-reported, and neither validation of diseases nor age at diagnosis was included. Whether different biological systems might be affected differently from maternal chronodisruption and whether the disruption of TTFLs during pregnancy results in long-term changes in adult offspring, needs further investigation. On the other hand, maternal-fetal circadian communication and how signals during pregnancy can synchronize daily rhythms between the mother and the fetus is also critical for clinical problems such as preterm birth (Bates \& Herzog 2020). Recently, a protocol of a prospective cohort study to determine the role of circadian rhythm in pregnant women and to identify pregnancy indices such as gestational weight gain with birth and infant outcomes was described (Kaur et al. 2020). These results will provide much needed information on the effects of the circadian rhythm during pregnancy and its consequences on the fetal and the first year of life of the infant's growth.

In addition, several studies in chicken, rat or sheep embryos report that a functional molecular circadian clock is important for the developmental processes including tissue homeostasis, histogenesis during early chondrogenesis (Alagha et al. 2020) and the release of reproductive hormones into the fetal bloodstream (Gao et al. 2016). Disruptions of any or all of these processes could influence fetal organ development in utero, as well as long-term health. In contrast, a melatonin producing mutant Clock gene mouse strain, Clock $\Delta 19+M E L$, did not show any negative alterations on pregnancy outcomes such as mating, gestation length, litter size, or postnatal growth, and had minimal effects on growth or metabolic homeostasis of heterozygous offspring through adulthood (Varcoe et al. 2016).

Several studies observed both short- and long-term behavioral outcomes such as anxiety-like behavior in adult offspring when the maternal circadian system was disrupted during pregnancy (Voiculescu et al. 2016, Chaves et al. 2019). In a gestational hypomelatoninemia model, it has been shown that absence of maternal melatonin delays physical characteristics, neurodevelopmental and cognitive functions in rat male offspring (sex-dependent) and leads to deficits in hippocampal-dependent spatial learning and memory in adults (Motta-Teixeira et al. 2018). Again, with this experimental setup, it is difficult to distinguish whether these alterations are a direct result of melatonin restriction on pup development or an indirect response from impaired maternal behavior and physiology. However, the current literature favors early life experiences, such as constant light, or dim light at night, changing specific behaviors and brain functions in adult offspring which could possibly lead to multigenerational psychological and cognitive problems (Roman \& Karlsson 2013, Cisse et al. 2017, Salazar et al. 2018). However, it should also be noted that Strohmaier and colleagues reported no overall association of maternal history of rotating night shift work before pregnancy or shift work exposure during pregnancy with depression or anxiety in adolescent and young adult offspring (Strohmaier et al. 2019). The same limitations mentioned above for the study for Rada et al. (2020) apply here as both studies analyzed the same database. The overall implications on transgenerational health effects of maternal chronodisruption during pregnancy on offspring are summarized in Table 4.

Only a limited number of studies have used mutant/ knockout models of circadian rhythm genes or have dysregulated the circadian rhythm through environmental manipulations to determine possible effects on the placenta. Placental clock gene rhythms are reported for the human placenta (Perez et al. 2015) but the extent to which these expressions are rhythmic in vivo remains unclear. However, disruption of the clock machinery could affect placental function and local melatonin production. In this context, melatonin synthesis might reduce apoptosis in the villous cytotrophoblasts but enhance the survival of syncytiotrophoblast cells (Reiter et al. 2014). Recently, it was demonstrated that maternal melatonin pretreatment in lipopolysaccharide (LPS)-treated mice resulted in reduced levels of pro-inflammatory mediators such as NF-kB1 and IL-1 $\beta 6 \mathrm{~h}$ after exposure to LPS with melatonin in the placenta (Lee et al. 2019b). Unfortunately, the study investigated only a single IP injection of melatonin and did not include any dose-dependent experiments which would strengthen the association of the melatonin response. Additionally, melatonin seems to enhance placental perfusion and prevent arterial insufficiency, hypercoagulation, inflammatory and oxidative damage (Lee et al. 2019a), and also protect from hypoxia/reoxygenation-induced damage in placental trophoblasts by regulating autophagy and apoptosis (Sagrillo-Fagundes et al. 2018). Thus, even though the exact mechanisms are not known, the current data indicates the likely importance of maternal circadian signals such as melatonin, in driving rhythmic placental function (Chuffa et al. 2019). In addition, the raised triglyceride levels observed in human placentas from pregnancies with large-for-gestational age infants are found to be associated with upregulated expression of the clock gene BMAL1 (Papacleovoulou et al. 2017). Ohhashi and colleagues investigated 115 cases of placental abruption retrospectively and reported that abdominal pain and adverse perinatal outcomes 
Table 4 Summary of current literature from both animal and human studies on transgenerational health effects of maternal chronodisruption during pregnancy on offspring.

\begin{tabular}{|c|c|c|}
\hline Authors & Species or subjects & Major implications \\
\hline \multicolumn{3}{|l|}{ Animal studies } \\
\hline Varcoe et al. (2011) & $\begin{array}{l}\text { Albino Wistar female rats; chronic phase shifts } \\
\text { (CPS) in every 3-4 days }\end{array}$ & $\begin{array}{l}\text { Short-term and long-term gender and age dependent metabolic } \\
\text { alterations and metabolic syndrome (e.g. increased adiposity, } \\
\text { hyperleptinemia and alterations to glucose metabolism) }\end{array}$ \\
\hline Varcoe et al. (2016) & Clock $\Delta 19+M E L$ mice & $\begin{array}{l}\text { No negative effects on pregnancy outcomes, growth or } \\
\text { metabolic homeostasis in heterozygous offspring through to } \\
\text { adulthood }\end{array}$ \\
\hline Gao et al. (2016) & Pregnant ewes; dark deprivation & $\begin{array}{l}\text { Effects on the release of reproductive hormones into the fetal } \\
\text { bloodstream }\end{array}$ \\
\hline Salazar et al. (2018) & Sprague-Dawley rats; CPS in every $3-4$ days & Alterations on fetal adrenal function and transcriptome \\
\hline Chaves et al. (2019) & Mice; gestational jet lag protocol & $\begin{array}{l}\text { Pathological phenotype (e.g. altered heart structure and } \\
\text { function, altered bone thickness and strength) and impairment } \\
\text { in postnatal growth and effects on circadian behavior }\end{array}$ \\
\hline Voiculescu et al. (2016) & Wistar rats; prenatal continuous light exposure & $\begin{array}{l}\text { Short-term memory impairment in adult offspring with a } \\
\text { relationship between serotonin-melatonin axis }\end{array}$ \\
\hline $\begin{array}{l}\text { Motta-Teixeira et al. } \\
\text { (2018) }\end{array}$ & $\begin{array}{l}\text { Wistar rats, gestational hypomelatoninemia } \\
\text { model }\end{array}$ & $\begin{array}{l}\text { Long-term effects on neurogenesis, cognitive problems and } \\
\text { deficits in hippocampal-dependent spatial learning and } \\
\text { memory }\end{array}$ \\
\hline $\begin{array}{l}\text { Roman \& Karlsson } \\
\text { (2013) }\end{array}$ & Wistar rats; maternal constant light exposure & $\begin{array}{l}\text { Multigenerational chronic stress-associated disorders, } \\
\text { neurodevelopmental and behavioral outcomes (depressive- } \\
\text { like; anxiety-like behaviors etc.) }\end{array}$ \\
\hline Voiculescu et al. (2016) & Wistar rats; prenatal continuous light exposure & \\
\hline Cisse et al. (2017) & $\begin{array}{l}\text { Siberian hamsters; chronic exposure to light at } \\
\text { night }\end{array}$ & \\
\hline Salazar et al. (2018) & Sprague-Dawley rats; CPS in every 3-4 days & \\
\hline \multicolumn{3}{|l|}{ Human studies } \\
\hline Strohmaier et al. (2019) & $\begin{array}{l}\text { Female nurses with history of rotating night shift } \\
\text { work }(n=4044) \text { and their children }(n=4813)\end{array}$ & $\begin{array}{l}\text { No associations between night shift work before or during } \\
\text { pregnancy and risk of depression, anxiety or atopic dermatitis, } \\
\text { asthma or hay fever in the offspring }\end{array}$ \\
\hline
\end{tabular}

including perinatal death showed significant circadian variation (Ohhashi et al. 2017). These results suggest an association between circadian variations and placental pathology. It should be pointed out that the data was collected from interviews on or after admission which could be potentially biased. However, the authors did not report any causal relationship of circadian rhythms between risk factors for placental abruption and disease onset for every $6 \mathrm{~h}$ period in a day with a small study population.

\section{Circadian rhythm and lactation}

Changes in the circadian clock can also affect lactation. Lactation is controlled by the temporal organization of prolactin secretion. Thus, light conditions during lactation might affect the function of the circadian pacemaker. In rats, a study revealed that constant light during lactation induces increased weight gain and disrupts daily levels of glucose and triglycerides in offspring (Madahi et al. 2018). However, exposure to a light-dark cycle until postnatal day 90 did not restore either the normal metabolic state or the daily rhythm of AVP, VIP and PER1 in the SCN of adult rats indicating a permanent impairment to the SCN during lactation (Madahi et al. 2018). In addition, exposure to chronic light-dark phase shifts during the prepartum period was associated with increased milk fat and milk yield in the postpartum period despite decreased blood glucose preand postpartum (Suarez-Trujillo et al. 2020). Thus, less variation in central circadian rhythms provides a more constant milieu to support the onset of lactogenesis. More detailed studies will determine more possible effects of altered circadian rhythms on lactation and health of the offspring.

\section{Circadian rhythm, epigenetic programming and transgenerational epigenetics}

Epigenetic modifications provide plasticity in gene expression and cellular biology in multicellular organisms and can affect many physiological processes, including growth, aging and metabolism. Epigenetic modification is also a crucial regulator during development due to the depth and breadth of the epigenetic code. Epigenetic changes in the germ line may be temporary or permanent. In the case of the latter, these changes can be transmitted to subsequent generations (Boskovic \& Rando 2018). When fetal circadian rhythm programming occurs, its effects can be considered long-lasting and possibly transgenerational. Therefore, transgenerational epigenetics refers to the transmission of epigenetic information from mother to offspring and even to later generations. 
During the last decade, evidence increasingly demonstrates that conditions during pregnancy may have lifelong effects on offspring in both humans and animal models. Factors such as maternal malnutrition, prenatal stress, and exposure to medical and social drugs have all been shown to have adverse health consequences for adult offspring. Regulation of the circadian clock is also subject to epigenetic influence (Reszka \& Zienolddiny 2018, Oh et al. 2019, Singh et al. 2019). Since significant number of genes in peripheral tissues show circadian expression, replication-independent mechanisms must be crucial for this rhythmicity restoring appropriate epigenetic patterns at a given time of the day. For instance, diurnal epigenetic alteration of CpG methylation is observed in the mouse brain. In a paternal $\sim 150 \mathrm{~kb}$ Snord116 deletion mouse, a model for human Prader Willi syndrome (PWS), diurnal regulation of the circadian genes Per2, Cry1 and Clock lose their epigenetic diurnal rhythmicity (Powell et al. 2013). 4,355 differentially methylated CpG regions (DMR) in mouse cortex have been identified and in paternal Snord 116 deleted mice, 97\% of these DMR's lose their diurnal epigenetic rhythmicity (Coulson et al. 2018). Importantly, more than $50 \%$ of the mouse DMR's identified in mouse cortex are retained in humans (Coulson et al. 2018). Deletion of human paternal chromosome 15q11.1, which includes SNORD116, results in altered metabolism, increased appetite with resultant obesity and sleep disturbances, all features of diurnal rhythms in humans.

On the other hand, potential effects of light/dark cycles during pregnancy could influence health of offspring during development or into adulthood. Epigenetic mechanisms are dynamic biological processes that have potential to mediate genetic and environmental effects on circadian processes. In recent years, there has been an increasing number of studies emphasizing the role of DNA methylation in the regulation of circadian systems in humans and other mammals (Adams et al. 2017, Bukowska-Damska et al. 2017, Ramos-Lopez et al. 2018). For instance, offspring from dams exposed to stress during pregnancy by a combination of restraint and $24 \mathrm{~h}$ constant light exhibit altered expression of epigenetic-related biomarkers such as DNMT1, HDAC1, HDAC2 and $\mathrm{AcH} 3 \mathrm{~K} 14$ in the hippocampus as compared to offspring from non-stressed dams (Zheng et al. 2016). Epigenetic chromatin remodeling can, therefore, influence TTFL dynamics and the regulation of clock genes which are vital to the circadian system.

Shift work is associated with altered gene-specific DNA methylation of genes such as DLX5, IGF2AS, TP73, BACH2, JRK, RPS6KA2 that are linked to cancer and type-2 diabetes (e.g. KCNQ1) Jacobs et al. 2013, Bhatti et al. 2015, Adams et al. 2017). In addition, of eight circadian clock genes investigated, promoter hypomethylation of three, PER1, PER2 and BMAL1 was seen in rotating-shift workers (Reszka et al. 2018). In fact, in a previous comprehensive study, $65 \%$ of the 473,800 loci tested were found to be hypomethylated in blood among night shift workers when compared to day shift workers (Bhatti et al. 2015). If these methylation changes in blood are representative of other tissues, the observed epigenetic alterations with a general systemic loss of methylation may cause increased genomic instability and possible carcinogenic potential of shift work. In line with this, also in 2015, another study reported that longterm shift work may increase the risk of breast cancer via aberrant methylation of the miR-34b promoter which plays a key role in the p53 tumor suppressor network by decreasing the efficacy of an immunomediated tumor-suppressive response (Liu et al. 2015). Epigenetic regulation of the BMAL1, CLOCK and CRY1 genes may also contribute to increased breast cancer risk in shift workers (Samulin Erdem et al. 2017). A strength of this study is that it compared breast cancer cases and healthy subjects with well-matched and characterized night shift work exposure patterns. However, larger patient cohorts will be needed to confirm these initial observations. In a recent study, gestational jet lag in mice was used as a model for circadian rhythm disturbance during early development (Chaves et al. 2019). Pregnant mice were subjected to a regular light-dark cycle or to a repeated delayed or advanced jet lag protocol, with an $8 \mathrm{~h}$ delayed or advanced light-dark cycle repeated every 3 days (Chaves et al. 2019). In the experimental group, hypermethylation of the miR17-92 cluster, required for heart and bone development, was demonstrated in liver DNA (Chaves et al. 2019). This study provided mechanistic evidence that 'gestational circadian rhythm disturbance' is a Developmental Origins of Health and Disease hypothesis (DOHaD)-related risk factor that affects the epigenetic landscape and predisposes to later life adverse health effects, such as cardiovascular disease and skeletal defects. In addition, this study also demonstrated differential gene expression for the clock genes Bmal1, Clock and Cry2 indicating a disturbance in the circadian oscillator.

The hypothesis that shift work is also associated with genome-wide DNA methylation changes and epigenetic age acceleration was evaluated in an epigenome-wide association study with extracted DNA from whole blood samples in non-Hispanic white women (White et al. 2019). Again, the results revealed that shift work is associated with differentially methylated $\mathrm{CpG}$ regions in the epigenome (e.g. ZFHX3), consistent with possible long-term adverse health effects such as risk of breast cancer since ZFHX3 has been implicated to act as a tumor suppressor by inhibiting estrogen receptor function. Therefore, special care was taken to confirm that the women were breast cancer free at the time of blood sampling. Not surprisingly, the association is strongest at $\geq 10$ years of night shift work. It will be interesting to investigate whether the effects of these 
epigenetic changes persist into the next generation. In addition, recent data highlights a remarkable plasticity on chromatin states and dynamics in the genome during the circadian cycle. Epigenetic transitions seem to be crucial for the transcriptional reprogramming triggered by environmental cues (Pacheco-Bernal et al. 2019). Also, changes in the epigenetic signature of key placental circadian rhythm genes might affect placental function and impact fetal development and health later in life of the offspring. It will be of interest to determine if rhythmicity is in response to rhythmic maternal secretions of hormones, or by a local clock mechanism within the placenta or both. It will be interesting to determine if maternal chronodisruption results in altered epigenetic changes and epiphenotypes during pregnancy.

\section{Conclusion}

The recent discoveries of circadian regulation in reproductive tissues of both females and males suggests that it plays a crucial role in several aspects of fertility. The increasing numbers of shift workers in society, many of which are pregnant and lactating women, experience a series of circadian rhythm perturbations including altered sleep and activity patterns, melatonin release, body temperature and timing of food intake. These alterations may affect the developing fetus and effects may persist into adulthood. Understanding these potential risks is important for determining the safety and efficacy of chronotherapeutic approaches such as light or melatonin treatments. However, it is not possible to eliminate these concerns only with epidemiological studies. There is evidence that shift work during pregnancy increases the risk for poor pregnancy outcomes such as small offspring, miscarriage and preterm birth, but there are also reports demonstrating the suggested risk associated with shift work is small. However, currently, there is not sufficient evidence to restrict women from night shift work. Most of the studies in this research area investigating maternal shift work and its long-term health consequences suffer from small sample size, and non-standardized type and timing of night shift work. In addition, recent studies underline obvious individual differences even within the same group. To overcome the difficulties inherent in human studies, the use of animal models provides a reasonable alternative for investigating maternal chronodisruption and reproductive, neural, hormonal and behavioral system alterations. However, translational relevance of animal studies for humans has limitations and animal studies are not directly applicable to humans in many cases. Thus, caution for overextrapolating data from rodents to humans is also necessary. The 2017 Nobel Prize in Medicine award for discoveries of the molecular mechanisms controlling circadian rhythm genes reveals the great importance of this field for understanding basic biological systems and human health.

\section{Declaration of interest}

The author declares that there is no conflict of interest that could be perceived as prejudicing the impartiality of this review.

\section{Funding}

This work was supported by the Scientific and Technological Research Council of Turkey (TUBITAK) (SBAG 219S636).

\section{Acknowledgement}

The author would like to thank Dr James McGrath from Yale University School of Medicine, Department of Genetics, New Haven, CT, USA for critical reading and editing of the manuscript.

\section{References}

Adams CD, Jordahl KM, Copeland W, Mirick DK, Song X, Sather CL, Kelsey K, Houseman A, Davis S, Randolph T et al. 2017 Nightshift work, chronotype, and genome-wide DNA methylation in blood. Epigenetics 12 833-840. (https://doi.org/10.1080/15592294.2017.1366407)

Akiyama S, Ohta $\mathrm{H}$, Watanabe S, Moriya T, Hariu A, Nakahata N, Chisaka H, Matsuda T, Kimura Y, Tsuchiya S et al. 2010 The uterus sustains stable biological clock during pregnancy. Tohoku Journal of Experimental Medicine 221 287-298. (https://doi.org/10.1620/ tjem.221.287)

Alagha MA, Vago J, Katona É, Takacs R, van der Veen D, Zakany $\mathbf{R}$ \& Matta C 2020 A synchronized circadian clock enhances early chondrogenesis. Cartilage 1947603520903425. (https://doi. org/10.1177/1947603520903425)

Alvarez JD, Chen D, Storer E \& Sehgal A 2003 Non-cyclic and developmental stage-specific expression of circadian clock proteins during murine spermatogenesis. Biology of Reproduction 69 81-91. (https://doi.org/10.1095/biolreprod.102.011833)

Alvarez JD, Hansen A, Ord T, Bebas P, Chappell PE, Giebultowicz JM, Williams C, Moss S \& Sehgal A 2008 The circadian clock protein BMAL1 is necessary for fertility and proper testosterone production in mice. Journal of Biological Rhythms 23 26-36. (https://doi. org/10.1177/0748730407311254)

Astiz M \& Oster H 2018 Perinatal programming of circadian clockstress crosstalk. Neural Plasticity 2018 5689165. (https://doi. org/10.1155/2018/5689165)

Bates K \& Herzog ED 2020 Maternal-fetal circadian communication during pregnancy. Frontiers in Endocrinology 11 198. (https://doi.org/10.3389/ fendo.2020.00198)

Bebas P, Goodall CP, Majewska M, Neumann A, Giebultowicz JM \& Chappell PE 2009 Circadian clock and output genes are rhythmically expressed in extratesticular ducts and accessory organs of mice. FASEB Journal 23 523-533. (https://doi.org/10.1096/fj.08-113191)

Begtrup LM, Specht IO, Hammer PEC, Flachs EM, Garde AH, Hansen J, Hansen ÅM, Kolstad HA, Larsen AD \& Bonde JP 2019 Night work and miscarriage: a Danish nationwide register-based cohort study. Occupational and Environmental Medicine 76 302-308. (https://doi. org/10.1136/oemed-2018-105592)

Bhatti P, Zhang Y, Song X, Makar KW, Sather CL, Kelsey KT, Houseman EA \& Wang P 2015 Nightshift work and genome-wide DNA methylation. Chronobiology International 32 103-112. (https://doi.org/10.3109/074 20528.2014.956362)

Boden MJ, Varcoe TJ, Voultsios A \& Kennaway DJ 2010 Reproductive biology of female Bmal1 null mice. Reproduction 139 1077-1090. (https://doi.org/10.1530/REP-09-0523)

Boden MJ, Varcoe TJ \& Kennaway DJ 2013 Circadian regulation of reproduction: from gamete to offspring. Progress in Biophysics 
and Molecular Biology 113 387-397. (https://doi.org/10.1016/j. pbiomolbio.2013.01.003)

Boskovic A \& Rando OJ 2018 Transgenerational epigenetic inheritance. Annual Review of Genetics 52 21-41. (https://doi.org/10.1146/annurevgenet-120417-031404)

Brzezinski A, Saada A, Miller H, Brzezinski-Sinai NA \& Ben-Meir A 2018 Is the aging human ovary still ticking?: Expression of clock-genes in luteinized granulosa cells of young and older women. Journal of Ovarian Research 11 95. (https://doi.org/10.1186/s13048-018-0471-3)

Bukowska-Damska A, Reszka E, Kaluzny P, Wieczorek E, Przybek M, Zienolddiny S \& Peplonska B 2017 Sleep quality and methylation status of core circadian rhythm genes among nurses and midwives. Chronobiology International 34 1211-1223. (https://doi.org/10.1080/0 7420528.2017.1358176)

Cai C, Vandermeer B, Khurana R, Nerenberg K, Featherstone R, Sebastianski M \& Davenport MH 2019 The impact of occupational shift work and working hours during pregnancy on health outcomes: a systematic review and meta-analysis. American Journal of Obstetrics and Gynecology 221 563-576. (https://doi.org/10.1016/j.ajog.2019.06.051)

Chau YM, West S \& Mapedzahama V 2014 Night work and the reproductive health of women: an integrated literature review. Journal of Midwifery and Women's Health 59 113-126. (https://doi.org/10.1111/ jmwh.12052)

Chaves I, van der Eerden B, Boers R, Boers J, Streng AA, Ridwan Y, Schreuders-Koedam M, Vermeulen M, van der Pluijm I, Essers J et al. 2019 Gestational jet lag predisposes to later-life skeletal and cardiac disease. Chronobiology International 36 657-671. (https://doi.org/10.1 080/07420528.2019.1579734)

Chen L \& Yang G 2014 PPARs integrate the mammalian clock and energy metabolism. PPAR Research 2014 653017. (https://doi. org/10.1155/2014/653017)

Chen M, Xu Y, Miao B, Zhao H, Luo L, Shi H \& Zhou C 2016 Expression pattern of circadian genes and steroidogenesis-related genes after testosterone stimulation in the human ovary. Journal of Ovarian Research 9 56. (https://doi.org/10.1186/s13048-016-0264-5)

Cheng S, Liang X, Wang Y, Jiang Z, Liu Y, Hou W, Li S, Zhang J \& Wang Z 2016 The circadian clock gene regulates acrosin activity of sperm through serine protease inhibitor A3K. Experimental Biology and Medicine $\mathbf{2 4 1}$ 205-215. (https://doi.org/10.1177/1535370215597199)

Chu W, Zhai J, Xu J, Li S, Li W, Chen ZJ \& Du Y 2019 Continuous lightinduced PCOS-like changes in reproduction, metabolism, and gut microbiota in Sprague-Dawley rats. Frontiers in Microbiology 103145. (https://doi.org/10.3389/fmicb.2019.03145)

Chuffa LGA, Lupi LA, Cucielo MS, Silveira HS, Reiter RJ \& Seiva FRF 2019 Melatonin promotes uterine and placental health: potential molecular mechanisms. International Journal of Molecular Sciences 21 300. (https:// doi.org/10.3390/ijms21010300)

Cisse YM, Russart KLG \& Nelson RJ 2017 Depressive-like behavior is elevated among offspring of parents exposed to dim light at night prior to mating. Psychoneuroendocrinology 83 182-186. (https://doi. org/10.1016/j.psyneuen.2017.06.004)

Coulson RL, Yasui DH, Dunaway KW, Laufer BI, Vogel Ciernia A, Zhu Y, Mordaunt CE, Totah TS \& LaSalle JM 2018 Snord116-dependent diurnal rhythm of DNA methylation in mouse cortex. Nature Communications 9 1616. (https://doi.org/10.1038/s41467-018-03676-0)

Evans MC \& Anderson GM 2018 Integration of circadian and metabolic control of reproductive function. Endocrinology 159 3661-3673. (https://doi.org/10.1210/en.2018-00691)

Gao Q, Lv J, Li W, Zhang P, Tao J \& Xu Z 2016 Disrupting the circadian photo-period alters the release of follicle-stimulating hormone, luteinizing hormone, progesterone, and estradiol in maternal and fetal sheep. Journal of Reproduction and Development 62 487-493. (https:// doi.org/10.1262/jrd.2016-009)

Gao Y, Wu X, Zhao S, Zhang Y, Ma H, Yang Z, Yang W, Zhao C, Wang L \& Zhang Q 2019 Melatonin receptor depletion suppressed hCG-induced testosterone expression in mouse Leydig cells. Cellular and Molecular Biology Letters 24 21. (https://doi.org/10.1186/s11658-019-0147-z)

Gatford KL, Kennaway DJ, Liu H, Kleemann DO, Kuchel TR \& Varcoe TJ 2019 Simulated shift work disrupts maternal circadian rhythms and metabolism, and increases gestation length in sheep. Journal of Physiology 597 1889-1904. (https://doi.org/10.1113/JP277186)
Giannetto C, Carcangiu V, Luridiana S, Parmeggiani A \& Piccione G 2020 Twenty-four-hour rhythm patterns of plasma melatonin in short-day and long-day breeders maintained under natural environmental conditions. Chronobiology International In press. (https://doi.org/10.1080/0742052 8.2020.1772808)

Goldstein CA, O'Brien LM, Bergin IL \& Saunders TL 2018 The effect of repeated light-dark shifts on uterine receptivity and early gestation in mice undergoing embryo transfer. Systems Biology in Reproductive Medicine 64 103-111. (https://doi.org/10.1080/19396368.2017.1408 715)

Grajewski B, Whelan EA, Lawson CC, Hein MJ, Waters MA, Anderson JL, MacDonald LA, Mertens CI, Tseng CY, Cassinelli 2nd RT et al. 2015 Miscarriage among flight attendants. Epidemiology 26 192-203. (https:// doi.org/10.1097/EDE.0000000000000225)

Hattammaru M, Tahara Y, Kikuchi T, Okajima K, Konishi K, Nakajima S, Sato K, Otsuka K, Sakura H, Shibata S et al. 2019 The effect of night shift work on the expression of clock genes in beard hair follicle cells. Sleep Medicine 56 164-170. (https://doi.org/10.1016/j.sleep.2019.01.005)

Hodzic A, Ristanovic M, Zorn B, Tulic C, Maver A, Novakovic I \& Peterlin B 2013 Genetic variation in circadian rhythm genes CLOCK and ARNTL as risk factor for male infertility. PLoS ONE 8 e59220. (https://doi. org/10.1371/journal.pone.0059220)

Hsu CN \& Tain YL 2020 Light and circadian signaling pathway in pregnancy: programming of adult health and disease. International Journal of Molecular Sciences 21 2232. (https://doi.org/10.3390/ ijms21062232)

Jacobs DI, Hansen J, Fu A, Stevens RG, Tjonneland A, Vogel UB, Zheng T \& Zhu Y 2013 Methylation alterations at imprinted genes detected among long-term shiftworkers. Environmental and Molecular Mutagenesis $\mathbf{5 4}$ 141-146. (https://doi.org/10.1002/em.21752)

Johnson MH, Lim A, Fernando D \& Day ML 2002 Circadian clockwork genes are expressed in the reproductive tract and conceptus of the early pregnant mouse. Reproductive Biomedicine Online 4 140-145. (https:// doi.org/10.1016/s1472-6483(10)61931-1)

Jolley CC, Ukai-Tadenuma M, Perrin D \& Ueda HR 2014 A mammalian circadian clock model incorporating daytime expression elements. Biophysical Journal 107 1462-1473. (https://doi.org/10.1016/j. bpj.2014.07.022)

Kalsbeek A, Verhagen LA, Schalij I, Foppen E, Saboureau M, Bothorel B, Buijs RM \& Pevet P 2008 Opposite actions of hypothalamic vasopressin on circadian corticosterone rhythm in nocturnal versus diurnal species. European Journal of Neuroscience 27 818-827. (https://doi.org/10.1111/ j.1460-9568.2008.06057.x)

Kaur S, Teoh AN, Shukri NHM, Shafie SR, Bustami NA, Takahashi M, Lim PJ \& Shibata S 2020 Circadian rhythm and its association with birth and infant outcomes: research protocol of a prospective cohort study. BMC Pregnancy and Childbirth 20 96. (https://doi.org/10.1186/s12884020-2797-2)

Kobayashi M, Watanabe K, Matsumura R, Anayama N, Miyamoto A, Miyazaki H, Miyazaki K, Shimizu T \& Akashi M 2018 Involvement of the luteinizing hormone surge in the regulation of ovary and oviduct clock gene expression in mice. Genes to Cells 23 649-657. (https://doi. org/10.1111/gtc.12605)

Komada Y, Ikeda Y, Sato M, Kami A, Masuda C \& Shibata S 2019 Social jetlag and menstrual symptoms among female university students. Chronobiology International 36 258-264. (https://doi.org/10.1080/074 20528.2018.1533561)

Koshy A, Cuesta M, Boudreau P, Cermakian N \& Boivin DB 2019 Disruption of central and peripheral circadian clocks in police officers working at night. FASEB Journal 33 6789-6800. (https://doi.org/10.1096/ fj.201801889R)

Kumar Jha P, Challet E \& Kalsbeek A 2015 Circadian rhythms in glucose and lipid metabolism in nocturnal and diurnal mammals. Molecular and Cellular Endocrinology 418 74-88. (https://doi.org/10.1016/j. mce.2015.01.024)

Labyak S, Lava S, Turek F \& Zee P 2002 Effects of shiftwork on sleep and menstrual function in nurses. Health Care for Women International 23 703-714. (https://doi.org/10.1080/07399330290107449)

Lavialle M, Champeil-Potokar G, Alessandri JM, Balasse L, Guesnet P, Papillon C, Pevet P, Vancassel S, Vivien-Roels B \& Denis I 2008 An (n-3) polyunsaturated fatty acid-deficient diet disturbs daily locomotor activity, 
melatonin rhythm, and striatal dopamine in Syrian hamsters. Journal of Nutrition 138 1719-1724. (https://doi.org/10.1093/jn/138.9.1719)

Lawson CC, Whelan EA, Lividoti Hibert EN, Spiegelman D, Schernhammer ES \& Rich-Edwards JW 2011 Rotating shift work and menstrual cycle characteristics. Epidemiology 22 305-312. (https://doi. org/10.1097/EDE.0b013e3182130016)

Lawson CC, Rocheleau CM, Whelan EA, Lividoti Hibert EN, Grajewski B, Spiegelman D \& Rich-Edwards JW 2012 Occupational exposures among nurses and risk of spontaneous abortion. American Journal of Obstetrics and Gynecology 206 327.e1-327.e8. (https://doi.org/10.1016/j. ajog.2011.12.030)

Lee JY, Li S, Shin NE, Na Q, Dong J, Jia B, Jones-Beatty K, McLane MW, Ozen M, Lei J et al. 2019a Melatonin for prevention of placental malperfusion and fetal compromise associated with intrauterine inflammation-induced oxidative stress in a mouse model. Journal of Pineal Research 67 e12591. (https://doi.org/10.1111/jpi.12591)

Lee JY, Song H, Dash O, Park M, Shin NE, McLane MW, Lei J, Hwang JY \& Burd I 2019b Administration of melatonin for prevention of preterm birth and fetal brain injury associated with premature birth in a mouse model. American Journal of Reproductive Immunology 82 e13151. (https://doi.org/10.1111/aji.13151)

Li R, Cheng S \& Wang Z 2015 Circadian clock gene plays a key role on ovarian cycle and spontaneous abortion. Cellular Physiology and Biochemistry 37 911-920. (https://doi.org/10.1159/000430218)

Li C, Xiao S, Hao J, Liao X \& Li G 2018 Cry1 deficiency leads to testicular dysfunction and altered expression of genes involved in cell communication, chromatin reorganization, spermatogenesis, and immune response in mouse testis. Molecular Reproduction and Development 85 325-335. (https://doi.org/10.1002/mrd.22968)

Li Y, Li J, Hou Y, Huang L, Bian Y, Song G \& Qiao C 2020a Circadian clock gene clock is involved in the pathogenesis of preeclampsia through hypoxia. Life Sciences 247 117441. (https://doi.org/10.1016/j. Ifs.2020.117441)

Li Z, Li Y, Ren Y \& Li C 2020b High ambient temperature disrupted the circadian rhythm of reproductive hormones and changed the testicular expression of steroidogenesis genes and clock genes in male mice. Molecular and Cellular Endocrinology 500 110639. (https://doi. org/10.1016/j.mce.2019.110639)

Liang X, Cheng S, Jiang X, He X, Wang Y, Jiang Z, Hou W, Li S, Liu Y \& Wang Z 2013 The noncircadian function of the circadian clock gene in the regulation of male fertility. Journal of Biological Rhythms $\mathbf{2 8}$ 208-217. (https://doi.org/10.1177/0748730413486873)

Liu Y, Johnson BP, Shen AL, Wallisser JA, Krentz KJ, Moran SM, Sullivan R, Glover E, Parlow AF, Drinkwater NR et al. 2014 Loss of BMAL1 in ovarian steroidogenic cells results in implantation failure in female mice. PNAS 111 14295-14300. (https://doi.org/10.1073/pnas.1209249111)

Liu R, Jacobs DI, Hansen J, Fu A, Stevens RG \& Zhu Y 2015 Aberrant methylation of miR-34b is associated with long-term shiftwork: a potential mechanism for increased breast cancer susceptibility. Cancer Causes and Control 26 171-178. (https://doi.org/10.1007/s10552-0140494-z)

Madahi PG, Ivan O, Adriana B, Diana O \& Carolina E 2018 Constant light during lactation programs circadian and metabolic systems. Chronobiology International 35 1153-1167. (https://doi.org/10.1080/0 7420528.2018.1465070)

Mao H, Feng L \& Yang WX 2017 Environmental factors contributed to circannual rhythm of semen quality. Chronobiology International 34 411-425. (https://doi.org/10.1080/07420528.2017.1280046)

Marino JL, Holt VL, Chen C \& Davis S 2008 Shift work, hCLOCK T3111C polymorphism, and endometriosis risk. Epidemiology 19 477-484. (https://doi.org/10.1097/EDE.0b013e31816b7378)

Martin-Fairey CA, Zhao P, Wan L, Roenneberg T, Fay J, Ma X, McCarthy R, Jungheim ES, England SK \& Herzog ED 2019 Pregnancy induces an earlier chronotype in both mice and women. Journal of Biological Rhythms 34 323-331. (https://doi.org/10.1177/0748730419844650)

McCarthy R, Jungheim ES, Fay JC, Bates K, Herzog ED \& England SK 2019 Riding the rhythm of melatonin Through pregnancy to deliver on time. Frontiers in Endocrinology 10 616. (https://doi.org/10.3389/ fendo.2019.00616)

McKenna H \& Reiss IKM 2018 The case for a chronobiological approach to neonatal care. Early Human Development 126 1-5. (https://doi. org/10.1016/j.earlhumdev.2018.08.012)
Mereness AL, Murphy ZC \& Sellix MT 2015 Developmental programming by androgen affects the circadian timing system in female mice. Biology of Reproduction 92 88. (https://doi.org/10.1095/ biolreprod.114.126409)

Mereness AL, Murphy ZC, Forrestel AC, Butler S, Ko C, Richards JS \& Sellix MT 2016 Conditional deletion of Bmal1 in ovarian theca cells disrupts ovulation in female mice. Endocrinology 157 913-927. (https:// doi.org/10.1210/en.2015-1645)

Miller BH, Olson SL, Turek FW, Levine JE, Horton TH \& Takahashi JS 2004 Circadian clock mutation disrupts estrous cyclicity and maintenance of pregnancy. Current Biology 14 1367-1373. (https://doi.org/10.1016/j. cub.2004.07.055)

Mills J \& Kuohung W 2019 Impact of circadian rhythms on female reproduction and infertility treatment success. Current Opinion in Endocrinology, Diabetes, and Obesity 26 317-321. (https://doi. org/10.1097/MED.0000000000000511)

Minegishi S, Sagami I, Negi S, Kano K \& Kitagishi H 2018 Circadian clock disruption by selective removal of endogenous carbon monoxide. Scientific Reports 8 11996. (https://doi.org/10.1038/s41598018-30425-6)

Morales-Munoz I, Partonen T, Saarenpaa-Heikkila O, Kylliainen A, Polkki P, Porkka-Heiskanen T, Paunio T \& Paavonen EJ 2019 The role of parental circadian preference in the onset of sleep difficulties in early childhood. Sleep Medicine 54 223-230. (https://doi.org/10.1016/j. sleep.2018.10.039)

Morse D, Cermakian N, Brancorsini S, Parvinen M \& Sassone-Corsi P 2003 No circadian rhythms in testis: period1 expression is clock independent and developmentally regulated in the mouse. Molecular Endocrinology 17 141-151. (https://doi.org/10.1210/me.2002-0184)

Motta-Teixeira LC, Machado-Nils AV, Battagello DS, Diniz GB, AndradeSilva J, Silva Jr S, Matos RA, do Amaral FG, Xavier GF, Bittencourt JC et al. 2018 The absence of maternal pineal melatonin rhythm during pregnancy and lactation impairs offspring physical growth, neurodevelopment, and behavior. Hormones and Behavior 105 146-156. (https://doi.org/10.1016/j.yhbeh.2018.08.006)

Nehme PA, Amaral F, Lowden A, Skene DJ, Cipolla-Neto J \& Moreno CRC 2019 Reduced melatonin synthesis in pregnant night workers: metabolic implications for offspring. Medical Hypotheses 132 109353. (https://doi. org/10.1016/j.mehy.2019.109353)

Ni W, Liu K, Hou G, Pan C, Wu S, Zheng J, Cao J, Chen Q \& Huang X 2019 Diurnal variation in sperm DNA fragmentation: analysis of 11,382 semen samples from two populations and in vivo animal experiments. Chronobiology International 36 1455-1463. (https://doi.org/10.1080/07 420528.2019.1649275)

Nikpour M, Tirgar A, Hajiahmadi M, Hosseini A, Heidari B, Ghaffari F, Ebadi A, Nasiri F \& Firouzbakht M 2019 Shift work and metabolic syndrome: a multi-center cross-sectional study on females of reproductive age. Biomedical Reports 10 311-317. (https://doi. org/10.3892/br.2019.1205)

Novak CM, Harris JA, Smale L \& Nunez AA 2000 Suprachiasmatic nucleus projections to the paraventricular thalamic nucleus in nocturnal rats (Rattus norvegicus) and diurnal Nile grass rats (Arviacanthis niloticus). Brain Research 874 147-157. (https://doi.org/10.1016/s00068993(00)02572-5)

Obeysekare JL, Cohen ZL, Coles ME, Pearlstein TB, Monzon C, Flynn EE \& Sharkey KM 2020 Delayed sleep timing and circadian rhythms in pregnancy and transdiagnostic symptoms associated with postpartum depression. Translational Psychiatry 10 14. (https://doi.org/10.1038/ s41398-020-0683-3)

Oh G, Koncevicius K, Ebrahimi S, Carlucci M, Groot DE, Nair A, Zhang A, Krisciunas A, Oh ES, Labrie V et al. 2019 Circadian oscillations of cytosine modification in humans contribute to epigenetic variability, aging, and complex disease. Genome Biology 20 2. (https://doi. org/10.1186/s13059-018-1608-9)

Ohhashi M, Furukawa S \& Sameshima H 2017 Circadian variation in the onset of placental abruption. Journal of Pregnancy 20173194814. (https://doi.org/10.1155/2017/3194814)

Ortiz Á, Espino J, Bejarano I, Lozano GM, Monllor F, Garcia JF, Pariente JA \& Rodriguez AB 2010 The correlation between urinary 5-hydroxyindoleacetic acid and sperm quality in infertile men and rotating shift workers. Reproductive Biology and Endocrinology 8138. (https://doi.org/10.1186/1477-7827-8-138) 
Pacheco-Bernal I, Becerril-Perez F \& Aguilar-Arnal L 2019 Circadian rhythms in the three-dimensional genome: implications of chromatin interactions for cyclic transcription. Clinical Epigenetics 11 79. (https:// doi.org/10.1186/s13148-019-0677-2)

Papacleovoulou G, Nikolova V, Oduwole O, Chambers J, VazquezLopez M, Jansen E, Nicolaides K, Parker M \& Williamson C 2017 Gestational disruptions in metabolic rhythmicity of the liver, muscle, and placenta affect fetal size. FASEB Journal 31 1698-1708. (https://doi. org/10.1096/fj.201601032R)

Perez S, Murias L, Fernandez-Plaza C, Diaz I, Gonzalez C, Otero J \& Diaz E 2015 Evidence for clock genes circadian rhythms in human fullterm placenta. Systems Biology in Reproductive Medicine 61 360-366. (https://doi.org/10.3109/19396368.2015.1069420)

Peterlin A, Kunej T \& Peterlin B 2019 The role of circadian rhythm in male reproduction. Current Opinion in Endocrinology, Diabetes, and Obesity 26 313-316. (https://doi.org/10.1097/MED.0000000000000512)

Powell WT, Coulson RL, Crary FK, Wong SS, Ach RA, Tsang P, Alice Yamada N, Yasui DH \& Lasalle JM 2013 A Prader-Willi locus IncRNA cloud modulates diurnal genes and energy expenditure. Human Molecular Genetics 22 4318-4328. (https://doi.org/10.1093/hmg/ ddt281)

Rada S, Strohmaier S, Drucker AM, Eliassen AH \& Schernhammer ES 2020 Night shift work surrounding pregnancy and offspring risk of atopic disease. PLOS ONE 15 e0231784. (https://doi.org/10.1371/journal. pone.0231784)

Ramos-Lopez O, Samblas M, Milagro FI, Riezu-Boj JI, Crujeiras AB, Martinez JA \& Project M 2018 Circadian gene methylation profiles are associated with obesity, metabolic disturbances and carbohydrate intake. Chronobiology International 35 969-981. (https://doi.org/10.108 0/07420528.2018.1446021)

Reiter RJ, Tan DX, Tamura H, Cruz MH \& Fuentes-Broto L 2014 Clinical relevance of melatonin in ovarian and placental physiology: a review. Gynecological Endocrinology 30 83-89. (https://doi.org/10.3109/0951 3590.2013.849238)

Reschke L, McCarthy R, Herzog ED, Fay JC, Jungheim ES \& England SK 2018 Chronodisruption: an untimely cause of preterm birth? Best Practice and Research: Clinical Obstetrics and Gynaecology 52 60-67. (https://doi.org/10.1016/j.bpobgyn.2018.08.001)

Resuehr D, Wu G, Johnson RL, Jr, Young ME, Hogenesch JB \& Gamble KL 2019 Shift work disrupts circadian regulation of the transcriptome in hospital nurses. Journal of Biological Rhythms 34 167-177. (https://doi. org/10.1177/0748730419826694)

Reszka E \& Zienolddiny S 2018 Epigenetic basis of circadian rhythm disruption in cancer. Methods in Molecular Biology 1856 173-201. (https://doi.org/10.1007/978-1-4939-8751-1_10)

Reszka E, Wieczorek E, Przybek M, Jablonska E, Kaluzny P, BukowskaDamska A, Zienolddiny S \& Peplonska B 2018 Circadian gene methylation in rotating-shift nurses: a cross-sectional study. Chronobiology International 35 111-121. (https://doi.org/10.1080/074 20528.2017.1388252)

Rivera AS, Akanbi M, O'Dwyer LC \& McHugh M 2020 Shift work and long work hours and their association with chronic health conditions: a systematic review of systematic reviews with meta-analyses. PLOS ONE 15 e0231037. (https://doi.org/10.1371/journal.pone.0231037)

Roman E \& Karlsson O 2013 Increased anxiety-like behavior but no cognitive impairments in adult rats exposed to constant light conditions during perinatal development. Upsala Journal of Medical Sciences 118 222-227. (https://doi.org/10.3109/03009734.2013.821191)

Rosa D, Terzoni S, Dellafiore F \& Destrebecq A 2019 Systematic review of shift work and nurses' health. Occupational Medicine 69 237-243. (https://doi.org/10.1093/occmed/kqz063)

Rutters F, Lemmens SG, Adam TC, Bremmer MA, Elders PJ, Nijpels G \& Dekker JM 2014 Is social jetlag associated with an adverse endocrine, behavioral, and cardiovascular risk profile? Journal of Biological Rhythms 29 377-383. (https://doi.org/10.1177/0748730414550199)

Sagrillo-Fagundes L, Assuncao Salustiano EM, Ruano R, Markus RP \& Vaillancourt C 2018 Melatonin modulates autophagy and inflammation protecting human placental trophoblast from hypoxia/reoxygenation. Journal of Pineal Research 65 e12520. (https://doi.org/10.1111/ jpi.12520)

Salazar ER, Richter HG, Spichiger C, Mendez N, Halabi D, Vergara K, Alonso IP, Corvalan FA, Azpeleta C, Seron-Ferre M et al. 2018 Gestational chronodisruption leads to persistent changes in the rat fetal and adult adrenal clock and function. Journal of Physiology 596 5839-5857. (https://doi.org/10.1113/JP276083)

Samulin Erdem J, Skare Ø, Petersen-Overleir M, Noto HØ, Lie JS, Reszka E, Peplonska B \& Zienolddiny S 2017 Mechanisms of breast cancer in shift workers: DNA methylation in five core circadian genes in nurses working night shifts. Journal of Cancer 8 2876-2884. (https://doi. org/10.7150/jca.21064)

Scarinci E, Tropea A, Notaristefano G, Arena V, Alesiani O, Fabozzi SM, Lanzone A \& Apa R 2019 'Hormone of darkness' and human reproductive process: direct regulatory role of melatonin in human corpus luteum. Journal of Endocrinological Investigation 42 1191-1197. (https://doi. org/10.1007/s40618-019-01036-3)

Sellix MT 2015 Circadian clock function in the mammalian ovary. Journal of Biological Rhythms 307-19. (https://doi.org/10.1177/0748730414554222)

Singh K, Jha NK \& Thakur A 2019 Spatiotemporal chromatin dynamics - a telltale of circadian epigenetic gene regulation. Life Sciences $\mathbf{2 2 1}$ 377-391. (https://doi.org/10.1016/j.lfs.2019.02.006)

Stock D \& Schernhammer E 2019 Does night work affect age at which menopause occurs? Current Opinion in Endocrinology, Diabetes, and Obesity 26 306-312. (https://doi.org/10.1097/ MED.0000000000000509)

Stock D, Knight JA, Raboud J, Cotterchio M, Strohmaier S, Willett W, Eliassen AH, Rosner B, Hankinson SE \& Schernhammer E 2019 Rotating night shift work and menopausal age. Human Reproduction $\mathbf{3 4}$ 539-548. (https://doi.org/10.1093/humrep/dey390)

Streuli CH \& Meng QJ 2019 Influence of the extracellular matrix on cellintrinsic circadian clocks. Journal of Cell Science 132 jcs207498. (https:// doi.org/10.1242/jcs.207498)

Strohmaier S, Devore EE, Vetter C, Eliassen AH, Rosner B, Okereke OI \& Schernhammer ES 2019 Night shift work before and during pregnancy in relation to depression and anxiety in adolescent and young adult offspring. European Journal of Epidemiology 34 625-635. (https://doi. org/10.1007/s10654-019-00525-2)

Suarez-Trujillo A, Wernert G, Sun H, Steckler TS, Huff K, Cummings S, Franco J, Klopp RN, Townsend JR, Grott M et al. 2020 Exposure to chronic light-dark phase shifts during the prepartum nonlactating period attenuates circadian rhythms, decreases blood glucose, and increases milk yield in the subsequent lactation. Journal of Dairy Science $\mathbf{1 0 3}$ 2784-2799. (https://doi.org/10.3168/jds.2019-16980)

Summa KC, Vitaterna MH \& Turek FW 2012 Environmental perturbation of the circadian clock disrupts pregnancy in the mouse. PLOS ONE 7 e37668. (https://doi.org/10.1371/journal.pone.0037668)

Sun M, Feng W, Wang F, Li P, Li Z, Li M, Tse G, Vlaanderen J, Vermeulen R \& Tse LA 2018 Meta-analysis on shift work and risks of specific obesity types. Obesity Reviews 19 28-40. (https://doi.org/10.1111/obr.12621)

Suzumori N, Ebara T, Matsuki T, Yamada Y, Kato S, Omori T, Saitoh S, Kamijima M, Sugiura-Ogasawara M \& Japan Environment \& Children's Study Group 2020 Effects of long working hours and shift work during pregnancy on obstetric and perinatal outcomes: a large prospective cohort study-Japan Environment and Children's Study. Birth 47 67-79. (https://doi.org/10.1111/birt.12463)

Tong Y, Guo H, Brewer JM, Lee H, Lehman MN \& Bittman EL 2004 Expression of haPer1 and haBmal1 in Syrian hamsters: heterogeneity of transcripts and oscillations in the periphery. Journal of Biological Rhythms 19 113-125. (https://doi.org/10.1177/0748730403262871)

Umemura Y \& Yagita K 2020 Development of the circadian core machinery in mammals. Journal of Molecular Biology 432 3611-3617. (https://doi. org/10.1016/j.jmb.2019.11.026)

Varcoe TJ, Wight N, Voultsios A, Salkeld MD \& Kennaway DJ 2011 Chronic phase shifts of the photoperiod throughout pregnancy programs glucose intolerance and insulin resistance in the rat. PLOS ONE 6 e18504. (https://doi.org/10.1371/journal.pone.0018504)

Varcoe TJ, Boden MJ, Voultsios A, Salkeld MD, Rattanatray L \& Kennaway DJ 2013 Characterisation of the maternal response to chronic phase shifts during gestation in the rat: implications for fetal metabolic programming. PLOS ONE 8 e53800. (https://doi.org/10.1371/journal. pone.0053800)

Varcoe TJ, Voultsios A, Gatford KL \& Kennaway DJ 2016 The impact of prenatal circadian rhythm disruption on pregnancy outcomes and longterm metabolic health of mice progeny. Chronobiology International 33 1171-1181. (https://doi.org/10.1080/07420528.2016.1207661)

Varcoe TJ, Gatford KL \& Kennaway DJ 2018 Maternal circadian rhythms and the programming of adult health and disease. American Journal of 
Physiology: Regulatory, Integrative and Comparative Physiology 314 R231-R241. (https://doi.org/10.1152/ajpregu.00248.2017)

Voiculescu SE, Le Duc D, Rosca AE, Zeca V, Chitimus DM, Arsene AL, Dragoi CM, Nicolae AC, Zagrean L, Schoneberg T et al. 2016 Behavioral and molecular effects of prenatal continuous light exposure in the adult rat. Brain Research 1650 51-59. (https://doi.org/10.1016/j. brainres.2016.08.031)

Wang Y, Gu F, Deng M, Guo L, Lu C, Zhou C, Chen S \& Xu Y 2016 Rotating shift work and menstrual characteristics in a cohort of Chinese nurses. BMC Women's Health 16 24. (https://doi.org/10.1186/s12905-0160301-y)

Welsh DK, Takahashi JS \& Kay SA 2010 Suprachiasmatic nucleus: cell autonomy and network properties. Annual Review of Physiology 72 551-577. (https://doi.org/10.1146/annurevphysiol-021909-135919)

White AJ, Kresovich JK, Xu Z, Sandler DP \& Taylor JA 2019 Shift work, DNA methylation and epigenetic age. International Journal of Epidemiology 48 1536-1544. (https://doi.org/10.1093/ije/dyz027)

Willis SK, Hatch EE, Wesselink AK, Rothman KJ, Mikkelsen EM \& Wise LA 2019 Female sleep patterns, shift work, and fecundability in a North American preconception cohort study. Fertility and Sterility 1111201. e1-1210.e1. (https://doi.org/10.1016/j.fertnstert.2019.01.037)

Xie M, Utzinger KS, Blickenstorfer K \& Leeners B 2018 Diurnal and seasonal changes in semen quality of men in subfertile partnerships. Chronobiology International 35 1375-1384. (https://doi.org/10.1080/0 7420528.2018.1483942)

Xu J, Li Y, Wang Y, Xu Y \& Zhou C 2016 Loss of Bmal1 decreases oocyte fertilization, early embryo development and implantation potential in female mice. Zygote 24 760-767. (https://doi.org/10.1017/ S0967199416000083)

Yoshinaka K, Yamaguchi A, Matsumura R, Node K, Tokuda I \& Akashi M 2017 Effect of different light-dark schedules on estrous cycle in mice, and implications for mitigating the adverse impact of night work. Genes to Cells 22 876-884. (https://doi.org/10.1111/gtc.12522)

Zhang L, Zhang Z, Wang F, Tian X, Ji P \& Liu G 2017 Effects of melatonin administration on embryo implantation and offspring growth in mice under different schedules of photoperiodic exposure. Reproductive Biology and Endocrinology 15 78. (https://doi.org/10.1186/s12958-017-0297-7)

Zhao W, Cui L, Huang X, Wang S, Li D, Li L, Sun Y \& Du M 2019 Activation of Rev-erbalpha attenuates lipopolysaccharide-induced inflammatory reactions in human endometrial stroma cells via suppressing TLR4regulated NF-kappaB activation. Acta Biochimica and Biophysica Sinica 51 908-914. (https://doi.org/10.1093/abbs/gmz078)

Zheng Y, Fan W, Zhang X \& Dong E 2016 Gestational stress induces depressive-like and anxiety-like phenotypes through epigenetic regulation of BDNF expression in offspring hippocampus. Epigenetics 11 150-162. (https://doi.org/10.1080/15592294.2016.1146850)

Received 30 May 2020

First decision 29 June 2020

Revised manuscript received 5 August 2020

Accepted 13 August 2020 